\title{
WOMEN JOURNALISTS IN SPAIN: AN ANALYSIS OF THE SOCIODEMOGRAPHIC FEATURES OF THE GENDER GAP
}

\author{
Mujeres periodistas en España: \\ análisis de las características sociodemográficas \\ y de la brecha de género
}

Roberto De-Miguel, Thomas Hanitzsch, Sonia Parratt and Rosa Berganza

Nota: Este artículo se puede leer en español en:

http://www.elprofesionaldelainformacion.com/contenidos/2017/may/16_esp.pdf

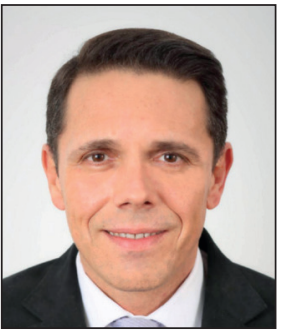

Roberto De-Miguel has a B.S. and Ph.D. in Communication Sciences from Complutense University of Madrid, and is currently a professor in the School of Communication Sciences at King Juan Carlos University (Madrid, Spain). His main research interests include: theory of communication, public opinion, political communication, and methods and techniques of communication research. He has participated in nine national competitive projects and two international ones. He has a wide scientific production in communication sciences and social sciences. He is the author of five monographs related to research on human communicative phenomena.

http://orcid.org/0000-0001-8911-8272

Universidad Rey Juan Carlos, Facultad de Ciencias de la Comunicación Camino del Molino, s/n. 28943 Fuenlabrada (Madrid), Spain roberto.demiguel@urjc.es

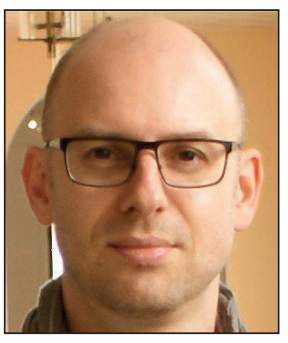

Thomas Hanitzsch is chair and professor of Communication in the Department of Communication Studies and Media Research at LMU Munich, Germany. A former journalist, his teaching and research focuses on global journalism cultures, war coverage, celebrity news and comparative methodology. He was Editor-in-Chief for Communication theory (2011-2015) and has co-edited The handbook of journalism studies (Routledge, 2009) and The handbook of comparative communication research (Routledge, 2012). He is leading the Worlds of Journalism Study, a multinational and collaborative endeavor to trace journalism cultures and investigate the profession's transformation around the world.

http://orcid.org/0000-0002-7104-6300

http://www.worldsofjournalism.org

LMU Munich Oettingenstr. 67, 80538 Munich, Germany Thomas.Hanitzsch@ifkw.Imu.de

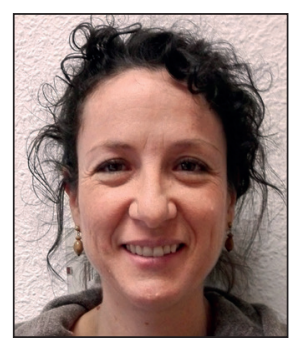

Sonia Parratt has a B.S. in Information Science from the University of Basque Country and a European Ph.D. in Journalism from the University of Santiago de Compostela. She is a professor in the Department of Journalism I at the Complutense University of Madrid (Spain). Her research interests include: journalistic genres, analysis of journalistic messages in the press, journalism and literature, and environmental journalism.

http://orcid.org/0000-0001-8501-3115

Universidad Complutense de Madrid, Facultad de Ciencias de la Información Av. Complutense, s/n. 28040 Madrid, Spain sfparratt@ccinf.ucm.es 


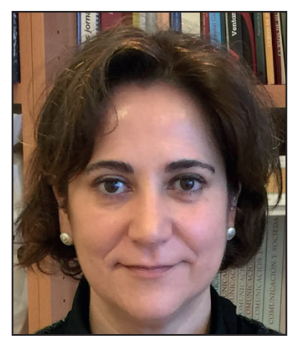

Rosa Berganza is chair professor of Journalism at King Juan Carlos University (Madrid, Spain). She has a wide experience as principal investigator in national and comparative international projects in journalism and political communication. She is an expert in quantitative techniques for social research, especially in content analysis and surveys. She has worked as a principal researcher on national projects and on others financed by international organizations and by the European Commission. Among the latter can be found Infocore (project 613308 in the $7^{\text {th }}$ Framework Program) and Cost action IS1308 on Communication and Populist Parties in Europe. She is a member of $\mathrm{Ne}$ pocs (Network of European Political Communication Scholars) and is principal researcher for Spain in the Worlds of Journalism Study.

http://orcid.org/0000-0001-9862-2550

Universidad Rey Juan Carlos, Facultad de Ciencias de la Comunicación Camino del Molino, s/n. 28943 Fuenlabrada (Madrid), Spain rosa.berganza@urjc.es

\begin{abstract}
Sociodemographic features and their relative weight related to the gender gap between male and female journalists in Spain are analyzed. A national representative survey of 390 journalists was carried out as part of an international study "Worlds of journalism". The results show that patterns of female inequality within Spanish media companies are routinely cited in scientific literature (underrepresentation, barriers in their professional careers, and lower salaries than men). The results also confirm the $3 R$ hypothesis (ratio of Recurrent and Reinforced Residuum): men hold three quarters of the posts with managerial responsibility and make two thirds of the decisions related to content, in spite of the fact that female journalists have higher levels of academic education and are therefore better trained for journalistic practice. Women are also paid lower salaries and tend to hold positions with a higher editorial responsibility in digital media, where the greatest progress towards equality is shown.
\end{abstract}

\title{
Keywords
}

Women; Female journalists; Spain; Gender gap; Sociodemographic features; Worlds of journalism study.

\section{Resumen}

Se analizan las características sociodemográficas y su peso relativo en la brecha de género entre los/as periodistas españoles/as. Para ello se realizó una encuesta nacional representativa a 390 periodistas dentro del estudio internacional "Worlds of journalism study". Los resultados muestran que los patrones de desigualdad femenina más citados en la bibliografía científica (infrarrepresentación, barreras en la carrera profesional y salarios inferiores) prevalecen en las empresas de comunicación españolas. También confirman la hipótesis de las 3R (la ratio del Residuo Reforzado Recurrente): los hombres ocupan tres cuartas partes de los cargos de máxima responsabilidad gerencial y dos tercios de los puestos de toma de decisiones sobre contenidos, a pesar de que ellas poseen mayor formación académica y mayor nivel de estudios de capacitación en la práctica del periodismo. Ellas obtienen, además, salarios inferiores y tienden a ocupar cargos de mayor responsabilidad editorial en los medios digitales, donde se observan mayores avances hacia la igualdad.

\section{Palabras clave}

Mujeres; Periodistas; España; Brecha de género; Características sociodemográficas; Worlds of journalism study.

De-Miguel, Roberto; Hanitzsch, Thomas; Parratt, Sonia; Berganza, Rosa (2017). "Women journalists in Spain: An analysis of the sociodemographic features of the gender gap". El profesional de la información, v. 26, n. 3, pp. 497-506.

https://doi.org/10.3145/epi.2017.may.16

\section{Introduction}

While the underrepresentation of women in journalism has been studied extensively, work that exhaustively examines and analyzes the specific labor issues faced by female journalists, even though increasingly frequent, has only been produced quite recently. Some authors point to the so-called "feminization of journalism hypothesis" (Van-Zoonen, 1998; Soriano; Cantón; Díez, 2011), according to which the increasing numbers of women in the profession has the potential to transform, first, the socio-demographic structure of the group, and then, its professional practices as well as the media content it produces. These suppositions, gathe- red under the common rubric of "feminine journalistic empowerment," constitute the inspiration for our essay.

According to the European Institute for Gender Equality, women journalists face several difficulties, one of which, according to the institute, is that men and women continue to be segregated according to role, status level, and prestige and/ or responsibilities (European Institute for Gender Equality EIGE-, 2013).

As far as scientific research is concerned, one of the most relevant pioneering works on the inequality of both access and upward mobility in the profession of journalism was carried out by Ramona Rush and her colleagues (Rush; Ou- 
krop; Ernst, 1972). These authors formulated the "Ratio of Recurrent and Reinforced Residuum," or the "R3 hypothesis," according to which women in journalism are concentrated among the lowest rungs of professional ladder with respect to their occupational status, salary levels, and even in terms of symbolic representation. "For a variety of countries, in Europe and beyond, it has been confirmed that the ratio stands at one woman for every three or four men, depending on the socioeconomic development of the nation under consideration (EFJ, 2012; Global media monitoring project, 2015; Rush, 1989; Rush; Buck; Ogan, 1982; Rush; Oukrop; Sarikakis, 2005; Gallagher, 2001; Worlds of journalism study, 2016). In other words, women generally occupy positions with less influence over media programming and business decisions.

Men and women continue to be segregated according to role, status level, and prestige and/or responsibilities (European Institute for Gender Equality, 2013)

Similarly, Brescoach, DiGuglielmo and Thornberry (1998) confirmed in their study that, while women's representation in the news sector had improved, it nevertheless had not yet reached the $50 \%$ mark. However, the situation has changed significantly in a number of countries since then. Today, women have come to constitute the majority of journalists in, among others, Bulgaria, Estonia, Finland, Lithuania, Romania, Serbia and Spain -at least for those who work for media companies and they are not self emplyed-workers- (EFJ, 2012; Global media monitoring project, 2015; APM, 2015; Worlds of journalism study, 2016). In addition, men predominantly occupied the upper echelons of the organizational ladder. Even so, the authors noted advances toward equality in mass communication's most novel formats (in the thenincipient phenomenon of digital journalism), where they observed signs that the profession would achieve greater hierarchical equity in the future (Brescoach; DiGuglielmo; Thornberry, 1998, p. 72).

Fifteen years later, the European Institute for Gender Equality's report (EIGE, 2013) newly confirmed the underrepresentation of female journalists in the higher ranks of the editorial hierarchy. In the media organizations that this entity analyzed, women represented less than a third of positions involving significant responsibility and were instead concentrated in those involving less decision-making power. At the highest rungs of the ladder, only $16 \%$ of women journalists performed CEO's functions, while at lower operating levels in the hierarchy (directors, subdirectors, and chief editors) their presence rose to $33 \%$. Apart from giving theoretical weight to claims about the persistence of gender inequality in the profession, these discoveries illustrate the loss of skilled human resources as posed by the $3 R$ hypothesis.

\section{Theoretical framework}

The International Women's Media Foundation (IWMF) has become the main observatory of gender equality in the news media at a global scale. In its 2011 report (Global report on the status of women in the news media), it interviewed 170,000 women in executive positions in over 500 news organizations in a total of 59 countries. By means of a 12-page questionnaire, it collected information on the hierarchical distribution of women in companies, salaries, recruitment, as well as contractual and promotional policies, among several other factors determining the real status of women journalists in news organizations.

In the first place, it is worth noting that, according to the set of results presented in the report, in 2010 men occupied most of the managerial positions in the countries analyzed. The researchers discovered that $73 \%$ of the positions of maximum corporate responsibility were held by men, as were two-thirds of those positions with decision power over content. This trend was not observed, however, in the segment made up of the most veteran journalists, within which the distribution of reportorial and editorial responsibilities was practically equal to that of men. Nor did the researchers observe signs of regression as far as the promotion of female journalists was concerned, given that the representation of women at the top of the profession has doubled since 1995, the same year in which a study by Margaret Gallagher (1995) revealed that women, on average, occupied only $12 \%$ of the highest rungs on the journalism's organizational ladder. Still, this does not mean that barriers to promotion have been completely eliminated, given that they were found in 20 of the 59 countries analyzed, even if almost half of the organizations had already taken measures to foment gender equality.

\section{The International Women's Media Foundation (IWMF) has become the main observatory of gender equality in the news media at a global scale}

The IWMF study also provides an x-ray of Spanish women journalists throughout eleven media formats. Taken together, the labor force includes 12,000 workers, $40 \%$ of whom are women, which demonstrates, according to the authors of the study, that even when women enjoy significant access to the profession, they find themselves below parity vis-à-vis their male counterparts. The location of women in the occupational hierarchy reveals other specific forms of gender marginalization in journalism. Despite the fact that the most veteran women reporters have broken through the glass ceiling at the intermediate-high rungs of the ladder, where they are represented as nearly half of all editors-in-chief, media directors, and positions of editorial responsibility, the number of women in supervisory roles turns out to be lower in absolute terms: women hold only 
one-fifth of those positions with direct responsibility over corporate decisions at the highest level.

On the other hand, moderate feminine representation at the junior level (34.6\%) suggests, according to the authors of the study, that there may exist a growing body of qualified women who are strategically increasing their experience and skill-sets in order to advance into the upper ranks of their profession (IMWF, 2011, p. 37). This is what Monika Djerf-Pierre (2007) calls, in the case of Sweden, a "competitive empowerment strategy," something we will be addressing below.

\section{Women hold only one-fifth of those po- sitions with direct responsibility over corporate decisions at the highest level (IWMF, 2011)}

As for salary levels, the results of the study indicate that the remuneration enjoyed by men and women were similar at lower and medium occupational levels, although variable at the highest levels as well as in cases of extraordinary complements to those salaries (e.g., in the distribution of bonuses for working on weekends and nights or for seniority within the company), the beneficiaries of which were mainly men.

A few years after the IWMF finished its study, within the context of Spain, the Informe anual de la profesión periodística (IAPP) carried out by the Asociación de la Prensa de Madrid (APM, 2014; 2015) confirmed some of the former report's results, although it also offered a glimpse of how the situation for women journalists had in fact improved. According to the results of the report, distribution by gender within the profession is quite balanced, at $52 \%$ men and $48 \%$ women (four points above the IWMF's estimate in 2010, later published in 2011). This proportion reverses when only journalists who work for news organizations (not freelancers) are taken into consideration: in this case, women represent $52 \%$ and men $48 \%$.

As this study reflects, the representation of women in the media has grown in recent years, and women have moved from being a majority solely in print media to one in audiovisual and digital formats as well. This growth has given way to similar variations in the structures of power distribution. Proof of this is an increase of four percentage points in the number of women managers in print media, eight (from $28 \%$ to $36 \%$ ) in the case of audiovisual media, and two in digital media. The report likewise underscores that figures in the fields of corporate and institutional news are favorable for women journalists: independently of their contractual arrangements or whether they work full- or part-time, the number of women hired or who preside over press bureaus or media agencies is higher than that of men. In the Spanish context, the emergence of new born-digital media after the financial crisis starting in 2008 can improve the situation. Between 2008 and 2013, at less 297 new digital media outlets were created by journalist (Berganza; Arcila-Calderón; Herrero-Jiménez, 2015, p. 180).
As for the average age of journalists, women are conspicuously younger ( 36 years old) than their male counterparts (46 years old), but this inequality contains a correlation as far as salaries are concerned: younger women journalists are more poorly remunerated than men and the salaries of those who have dedicated the most years to their profession are also lower than the highest salaries earned by male journalists. This may be explained, as we will see below, by way of the appreciable gender inequality at the executive and upper managerial levels. The younger average age of women journalists can also be explained to still prevalent cultural inequalities in terms of gender roles. Some women journalists therefore might decide to leave the profession at a fairly young age, when they find it hard to reconcile family life with working as journalist (with sometimes unpredictable working hours).

Given these initial assessments, our study attempts to respond to two wide research topics posed by the tentative solutions offered by the bibliography to the situation of women in journalism. Likewise, its takes a step toward a theoretical consolidation of findings made by several authors. In this way, this empirical study is aimed at responding to the following research questions.

RQ 1: What are the defining characteristics of currently existing gender inequality among male and female Spanish journalists?

RQ 2: To what degree do sociodemographic variables influence the situation of journalists at their places of employment?

\section{Methodology}

We apply a quantitative methodology whose observational tool consists of a closed individual questionnaire directed to a representative sample of the population of Spanish journalists. The survey was carried out between 2014 and 2015 thanks to financing and cooperation provided by $L M U M U$ nich, where the Worlds of journalism study is hosted::

htp://www.worldsofjournalism.org

Regarding the sample design, for the selection of units we gathered the census data on Spanish media included in both the APM report (2013) and the Agenda de la comunicación (Dirección General de Comunicación de la Secretaría de Estado de Comunicación, 2013). We utilized cluster sampling, using the media or header as the added sampling unit. We selected a total of 124 media organizations (newspapers, news agencies, radio stations, television channels, magazines, and digital media), both publicly and privately owned, stratified according to size (large/small) and autonomous community. The method of extraction was multistage sampling (by clusters, stratified and aleatory during the last stage). We randomly selected five journalists from each large media outlet (i.e. with a workforce of over 100 journalists) as well as three from each small one. The final sample featured 390 valid questionnaires ( $n=390)$, with $95 \%$ confidence and $5 \%$ error $(2 \sigma)$, and took for reference the estimated population ( $n=18.000)$ for 2014 (Berganza; Herrero; Carratalá, 2016). Personal interviews were conducted over the telephone by a team of six researchers between March 1, 2014 and May 30, 2015. 


\section{Results}

In the report's results, given below, we examined the gender and occupational levels of the journalists under consideration not from a static, fixed standpoint but rather by incorporating the perspective of gender (according to which this condition "could affect" or could "be an effect") when analyzing both intergender social relations (between journalists of differing gender) and intra-gender social relations (between journalists of the same gender, according to their socio-professional status). As for practical effects, we took into account all the sociodemographic diversity that was registered by means of the observational tool, but have highlighted only the relevant findings.

\subsection{Intergender analysis}

After purging errors in the database, we performed a segmentation analysis by means of the division method called CRT (classification and regression trees), making it possible to identify the criteria that maximize the differences bet-

Table 1. Overview of the regression model
\begin{tabular}{|l|c|c|c|c|c|c|}
\hline \multicolumn{1}{|c|}{ Independent variables } & B & E.T. & Wald & gl & Sig. & Exp(B) \\
\hline Education (degrees attained) & 0.800 & 0.253 & 10.022 & 1 & 0.002 & 2.226 \\
\hline Salary & & & 6.223 & 2 & 0.045 & \\
\hline (1) Salary $(€<1,000)$ & -0.815 & 0.381 & 4.578 & 1 & 0.032 & 0.443 \\
\hline (2) Salary $(€<2,000)$ & 0.024 & 0.270 & 0.008 & 1 & 0.929 & 1.025 \\
\hline Type of media outlet & & & 4.643 & 2 & 0.098 & \\
\hline (1) Print media and agencies & -0.642 & 0.312 & 4.222 & 1 & 0.040 & 0.526 \\
\hline (2) TV and radio & -0.636 & 0.337 & 3.556 & 1 & 0.059 & 0.529 \\
\hline Type of degree & & & 8.089 & 3 & 0.044 & \\
\hline (1) Journalism & -1.273 & 0.489 & 6.762 & 1 & 0.009 & 0.280 \\
\hline (2) Other communication & -0.925 & 0.635 & 2.126 & 1 & 0.145 & 0.396 \\
\hline (3) Journalism or other & -0.587 & 0.734 & 0.639 & 1 & 0.424 & 0.556 \\
\hline Rank & & & 0.917 & 2 & 0.632 & \\
\hline (1) Senior & 0.188 & 0.375 & 0.250 & 1 & 0.617 & 1.206 \\
\hline (2) Junior & 0.253 & 0.275 & 0.840 & 1 & 0.359 & 1.287 \\
\hline Constant & 1.414 & 0.614 & 5.300 & 1 & 0.021 & 4.112 \\
\hline
\end{tabular}

ween variables and among homogenous groups of journalists (segments and profiles) collected around a certain variable of classification (dependent) so as, in this way, to offer only those results that are statistically significant from the multivariable intersections.

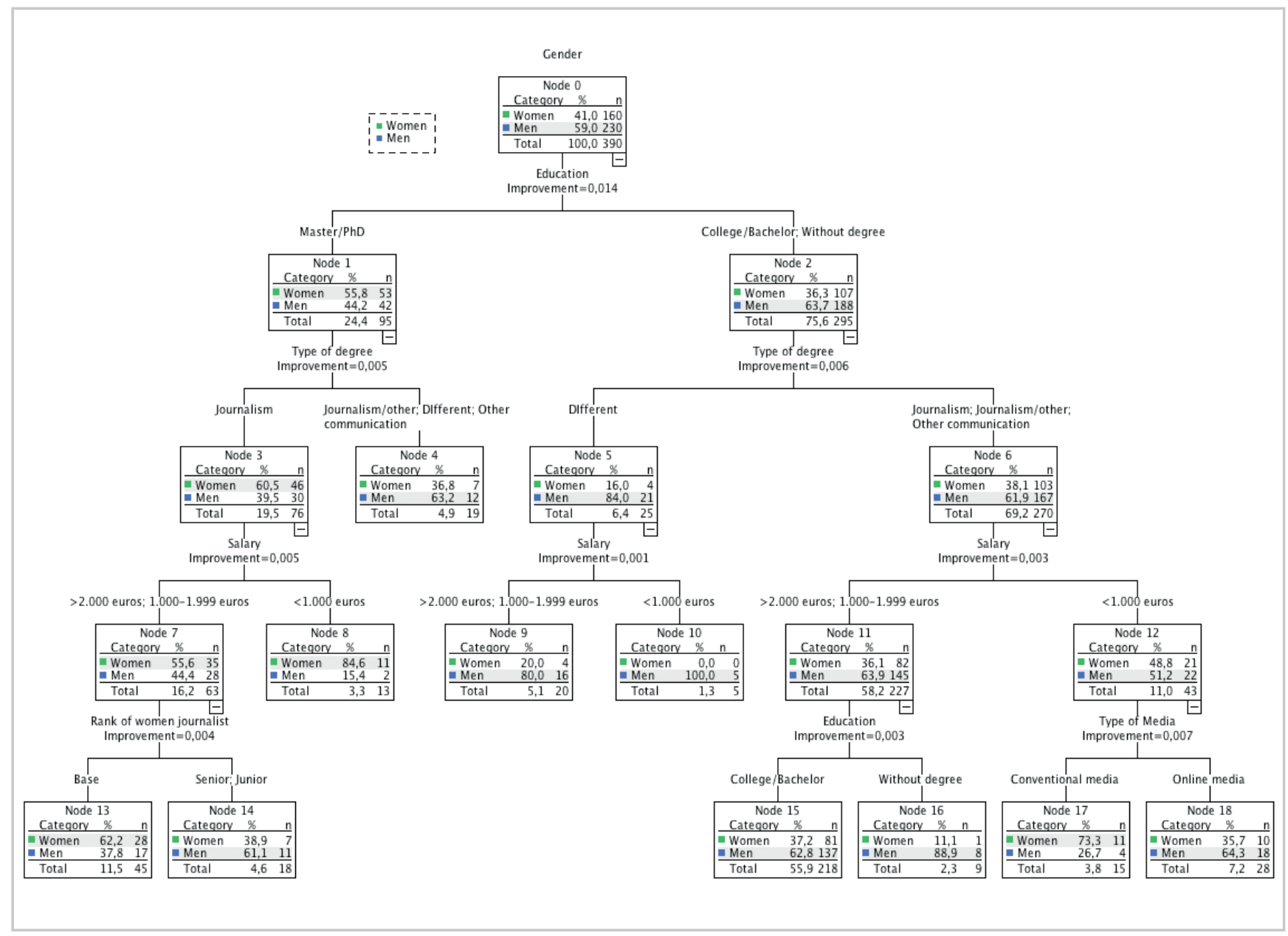

Figure 1. Segmentation tree of the journalist's gender. Method of growth: CRT; $\chi^{2}=29.183 ; p=0.001 ;$ correct classification: $65.9 \%$ 
The criteria or independent variables chosen for their relation to the theoretical framework were the following:

- educational attainment (university degrees: masters/doctoral degrees; without higher education):

- salary level (<1,000 euro; <2,000 euros; >2,000 euros);

- type of media outlet (print and agencies; radio and television; online media)

- type of degree (journalism; other degree in the field of communications; journalism and other degrees in the field of communications; degrees other than communications): and

- hierarchical rank (senior; junior; entry level).

The rest of the sociodemographic variables were excluded from the analysis due to their slight predictive power in the equation.

\section{Within the segment of journalists with} best qualified university degrees, precariousness (monthly net income less than 1,000 euros) correspond to women, which amount to $85 \%$ within this group

Table 1 offers an overview of the importance of the journalist's gender as a variable. The most relevant disparities occur in terms of educational attainment $(\beta=0.800$; $\mathrm{p}<0.01$ ), which reveals that the academic progress of women is the major differential feature between male and female journalists. In order of importance, the following discriminating factor is whether the journalist, male or female, has received the required qualification to be a practicing journalist: women stand out in that they more often have a degree in journalism $(\beta=-1.273 ; p=0.01)$. After this comes salary level, which indicates that women are more likely to earn less than 1,000 euros $(\beta=0.815 ; p<0.05)$; the type of media outlet for which women work, with a greater probability that they work in print media and agencies $(\beta=$ $-0.640 ; p<0.05)$; and finally, although with lesser predictive relevance, the rank the journalist has attained on the media outlet's corporate ladder.

Table 2. Hierarchical distribution of Spanish journalists

\begin{tabular}{|c|c|c|c|c|c|c|}
\hline & & \multicolumn{2}{|c|}{ Intergender } & \multirow{2}{*}{ Total } & \multicolumn{2}{|c|}{ Intragender } \\
\hline & & Women & Men & & Women & Men \\
\hline \multirow{2}{*}{ Senior } & $\%$ & 34.0 & 66.0 & 100 & \multirow{2}{*}{$10.0 \%$} & \multirow{2}{*}{$13.5 \%$} \\
\hline & $\mathrm{n}$ & 16 & 31 & 47 & & \\
\hline \multirow{2}{*}{ Junior } & $\%$ & 36.0 & 64.0 & 100 & \multirow{2}{*}{$20.0 \%$} & \multirow{2}{*}{$24.8 \%$} \\
\hline & $\mathrm{n}$ & 32 & 57 & 89 & & \\
\hline \multirow{2}{*}{ Base } & $\%$ & 44.1 & 55.9 & 100 & \multirow{2}{*}{$70.0 \%$} & \multirow{2}{*}{$61.7 \%$} \\
\hline & $n$ & 112 & 142 & 254 & & \\
\hline \multirow{2}{*}{ Total } & $\%$ & 41.0 & 59.0 & 100 & $100 \%$ & $100 \%$ \\
\hline & $\mathrm{n}$ & 160 & 230 & 390 & 160 & 230 \\
\hline
\end{tabular}

The analysis of the nodes of the segmentation tree (Figure 1) offers more detailed information about the professional situation of women journalists. One can observe that $62 \%$ of women with university training in journalism and who took additional higher education courses earn over one thousand net euros a month, even when they are found at the lowest positions of the media outlet's hierarchical ladder (node 13). In identical circumstances, this proportion becomes inverted when it reaches intermediate and upperlevel positions of the ladder (node 14): men occupy most of the junior and senior-level positions (60\%).

This inference is compatible with the use of a competition strategy, that is, when a woman seeks to maximize her academic potential (or intellectual capital) with the goal of catching up to men (Djerf-Pierre, 2007), even if she still ends up earning a lower salary than her male counterparts (Figure 2).

\section{The 2014 IAPP report offered a glimpse of how the situation for women journa- lists had in fact improved}

Within the segment of journalists with best qualified university degrees, precariousness (monthly net income less than 1,000 euros) correspond to women, which amount to $85 \%$ within this group (node 8 , figure 1 ). Considering the weight of this segment within the overall sample, it can be seen that of the 53 female journalists with third cycle studies, 11 $(21 \%)$ receive a precarious wage compared to the two men $(5 \%)$ that possess this same formative level.

Apart from the most educated group of the sample, professional intrusion, or the exercise of professional functions without the required training and certification, is primarily a masculine phenomenon (node 5): $84 \%$ of journalists without

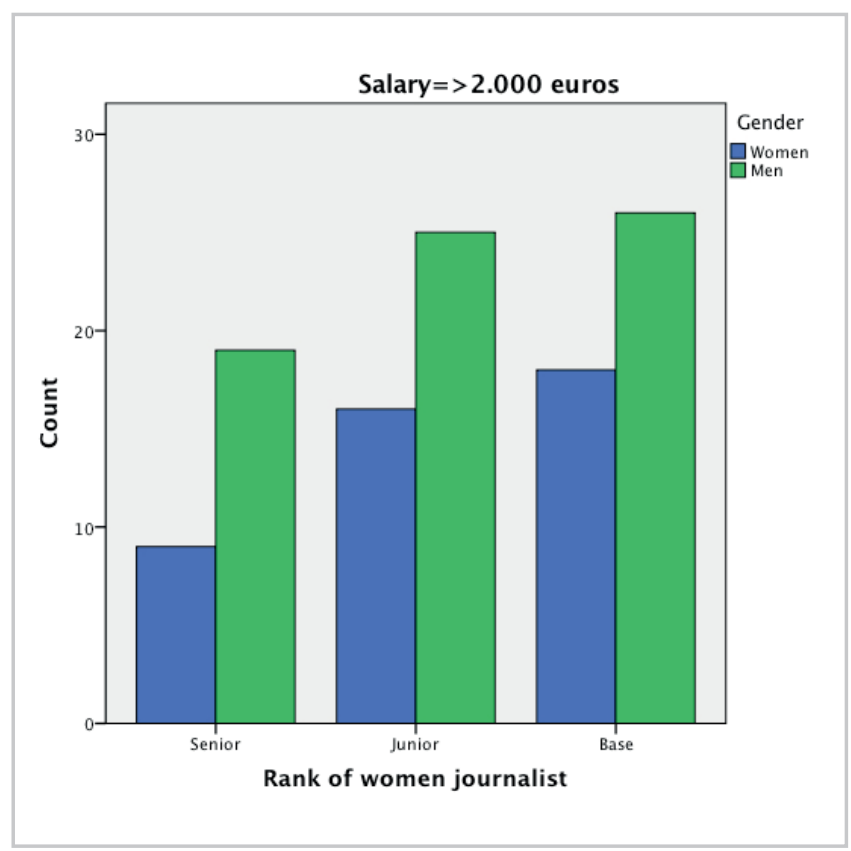

Figure 2. Salaries over 2,000 euros according to the rank and gender of the journalist 
specific training in the field of mass communications or in related areas of expertise are men (11\% of all male journalists), whereas only $4 \%$ of women practice the profession without possessing a qualifying degree in any of the mass media university studies. When a woman lacks specialization in the field of mass communication, she suffers from salary inequality too: in this situation, $80 \%$ of men earn over 1,000 euros (node 9). Therefore, one can see that the rule noted by Djerf-Pierre (2007, p. 100), according to which female journalists must confront their counterparts under unequal conditions when it comes to "validating their jobs in the public sphere," also applies to the Spanish context.

The job insecurity experienced by women in the labor market can also be explained by the type of media outlets for which they work. Three out of four female reporters who hold a university degree and earn less than 1,000 net euros a month work for traditional media outlets (node 17), whereas men without university degrees who do not earn that much are more heavily represented in digital media (node 18: $64 \%$ of men and $36 \%$ of women).

Notably, when the salary is 1,000 euros or higher, the possession of a university degree marks the difference between genders, given that within the segment of journalists without a university degree who earn the highest salaries, men account for nine out of ten cases. Again, education (the maximization of intellectual capital) is the variable that best predicts the position occupied by women within the idiosyncratic context of Spanish media.

Professional intrusion is primarily a masculine phenomenon: $84 \%$ of journalists without specific training in the field of mass communications or in related areas of expertise are men ( $11 \%$ of all male journalists)

\subsection{Intragender analysis}

Before beginning the analysis, we should make clear how the transversal focus on gender that we adopt here affects when interpreting our results. When the net distribution is examined, the differences are not very large. For example, there is $10 \%$ of senior-level women compared with $13.5 \%$ of men; and $20 \%$ of junior-level women compared with $24.8 \%$ of junior-level men. However, when the statistics between genders (in gross numbers) are examined, only one third of women occupy the senior (34\%) and junior (36\%) levels, compared with $66 \%$ and $64 \%$ of men, respectively. This suggests that we should place inequality amongst the lowest absolute proportion of women journalists working in the newsroom, although their distribution on the corporate ladder, within their gender, is equal to that of men (the $13.5 \%$ of men who have managerial jobs should in fact be multiplied by three because the proportion of women at the top scarcely reaches one third).
To carry out our intrageneric analysis, we chose to employ the same exploratory techniques that we used when comparing men and women. Still, our analysis of the distribution of power among women journalists primarily aims to obtain, by means of decision trees (segmentation analyses; CRT-Classification and regression trees) (Table 3), precise and homogenous subgroupings of cases in light of the journalist's rank as dependent variable.

$73 \%$ of women, regardless of the positions that they occupy, earn salaries below $€ 2,000$ a month

The factor most strongly associated with hierarchical status is the type of media outlet for which the woman journalist works $(\beta=-0.309 ; p<0.001)$ : the further from print journalism or agencies she finds herself, the greater the probability that she works in a high-ranking managerial position. After this, the second most predictive variable is the net salary she receives $(\beta=-0.362 ; p<0.001)$, which is logical if one takes into account that greater organizational status goes hand in hand with higher income. In third place can be found the number of media outlets for which she currently works, which demonstrates that the probability of finding women who work for various media outlets is significantly higher as one descends towards the base levels $(\beta=-0.164$; $\mathrm{p}<0.05$ ). The other elements (Degree: whether she possesses a specific degree in communications; and Education: the educational level she has attained) lack predictive value, demonstrating the scarce variability of these two factors among women, a feature that has already been noted in the intergender analysis.

The study of groups defined by segmentation analysis (Figure 3) reveals how these elements are combined around improvements in women's situation in the media. In the first place, $73 \%$ of women, regardless of the positions that they occupy, earn salaries below 2,000 euros a month (nodes 1 and 2), which in statistical terms does not distance them from their male colleagues (69\%) in a context of generalized job insecurity. What does make a difference is that the ratio of senior-level professionals who earn more than this amount stands at one woman for every two men (9/18); and that three out of every four managers with high salaries work in 


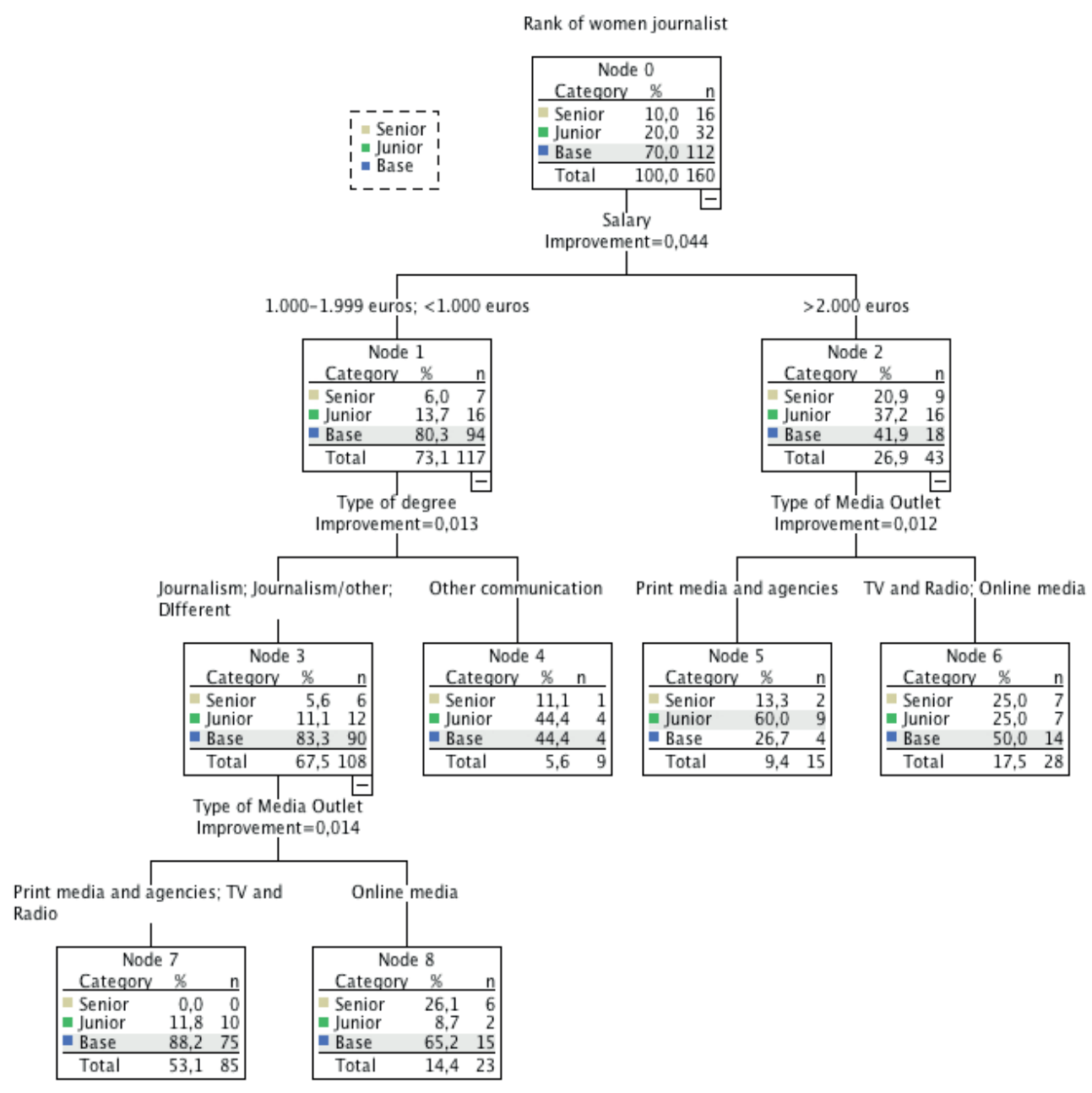

Figure 3. Segmentation tree of women journalists according to professional category. Method of growth: CRT; $\chi^{2}=26.911 ; p=0.001$; correct classification: $73,1 \%$

electronic media (radio, television, and online media) (node $6)$, formats that, moreover, turn out to be more equal in both census data and hierarchical terms: the net proportion of the most well-remunerated journalists almost inverts the $3 R$ rule in these forms of media where, on the other hand, half of all journalists achieve positions of editorial responsibility (senior and junior).

Results confirm the validity of the $3 R$ hypothesis: men occupy three-fourths of the positions with the greatest managerial responsibility and two-thirds of the positions involving decisions over content

All in all, the lower female demographics already noted affect women's real empowerment. While there are more women enjoying positions of editorial responsibility (senior and junior) in the traditional press than there are in the electronic and digital information platforms $(73.1 \%$ and
$50 \%$, respectively), what seems to be the dominant tendency is that, in absolute terms, less than a third of journalists occupying top positions in the traditional press earn over 2,000 net euros a month for their labors.

\section{Academic training is the factor that best predicts intergender differences in the media sector}

Upon examining the elements most closely linked to job insecurity, one understands why new digital information formats constitute a professional niche for many journalists who have managed to advance toward equality. Even when their salary is less than 2,000 euros a month, women managers have a presence that is three times larger in native digital media (node 8) than it is in traditional media (node 7), whereas in the latter case, the immense majority of women journalists (88.2\%) occupy the lowest rungs on the occupational ladder. 


\section{Conclusions}

The empirical study detailed in the preceding paragraph, despite its exploratory nature, constitutes an advance in the degree of generalization offered by the most part of the hypotheses upon which this project's questions were based. In the first place, our results confirm the validity of the $3 R$ hypothesis: men occupy three-fourths of the positions with the greatest managerial responsibility and two-thirds of the positions involving decisions over content. There is clear evidence of systemic discrimination against women journalists operating at several levels.

New digital news platforms constitute a niche in the labor market where one can see the most solid advances toward equality

The first of these levels of inequality concerns lower levels of female managerial representation at the top of the organizational hierarchy as much as it does uneven remuneration for their labor. These results confirm a phenomenon that has already been repeatedly exposed in reports issued by such observers as the IWMF (2011) or the EIGE (2013), who sounded alarms about the well-established structural character undergirding the lack of parity in these areas.

In the second place, one can observe that the residual concentration of women at the top of the media organizational ladder goes hand in hand with the maximization of their intellectual capital: their academic training is the factor that best predicts intergender differences in the media sector. It is not only that women journalists distinguish themselves from their male colleagues by extending their academic training beyond a mere university degree, but that their efforts are specifically directed at developing greater skills in the practice of journalism. The results of our analysis therefore back up the hypothesis offered by Monika Djerf-Pierre (2007) regarding women's use of competition strategies.

In the case of Spain, the maximization of intellectual capital is the main method used by women journalists to close the gender gap, although it is hardly the only one. New digital news platforms constitute a niche in the labor market where one can see the most solid advances toward equality. In accordance with what Djerf-Pierre (2007) has observed in Sweden, the situation of Spanish women journalists has also improved thanks to a strategy of expansion, in view of salary differences in the field and given that the ratio of the most highly remunerated women practically turns the $3 R$ upside down when it comes to digital media, where half of the women working in the sector enjoy positions of editorial responsibility (senior and junior). Even when their salary is lower than that of women executives working in traditional media, the presence of women managers in native digital media outlets is triple that found in the traditional press, were job insecurity affects $90 \%$ of women journalists on the workforce.

\section{Bibliografía}

APM (2010). Informe anual de la profesión periodística 2010. Madrid: Asociación de la Prensa de Madrid.

http://www.apmadrid.es/wp-content/uploads/2009/02/ Informe\%20APM\%202010.pdf

APM (2013). Informe anual de la profesión periodística 2013. Madrid: Asociación de la Prensa de Madrid.

http://www.apmadrid.es/wp-content/uploads/2009/02/ informe_profesion_2013.pdf

APM (2014). Informe anual de la profesión periodística 2014. Madrid: Asociación de la Prensa de Madrid.

http://www.apmadrid.es/wp-content/uploads/2009/02/ Informe\%20profesion_2014_def_baja.pdf

APM (2015). Informe anual de la profesión periodística. Madrid: Asociación de la Prensa de Madrid.

http://www.apmadrid.es/wp-content/uploads/2016/11/ INFORME-PROFESION-APM-2015_baja_7M.pdf

Berganza, Rosa; Arcila-Calderón, Carlos; Herrero-Jiménez, Beatriz (2016). "Digital vs. traditional media journalists: sociodemographic characteristics, and external and internal threats to autonomy". El profesional de la información, v. 25 , n. 2, pp. 179-187.

http://dx.doi.org/10.3145/epi.2016.mar.04

Berganza, Rosa; Herrero, Beatriz; Carratalá, Adolfo (2016). "La (des)confianza de los periodistas españoles hacia las instituciones públicas a partir del estudio de factores organizacionales". Anuario electrónico de estudios en comunicación social "Disertaciones", v. 9, n. 1, pp. 24-43.

http://dx.doi.org/10.12804/disertaciones.09.01.2016.02

Brescoach, W. W.; DiGuglielmo, T.; Thornberry, J. (1998). "Is the playing field level yet? A comparative study of women in mass media: 1970s-1990s" (documento inédito), University of Kentucky, Lexington, EUA.

Dirección General de Comunicación de la Secretaría de Estado de Comunicación (2013). Agenda de la comunicación. Madrid: Ministerio de la Presidencia. Secretaría General Técnica.

http://www.lamoncloa.gob.es/serviciosdeprensa/agendacom/ Documents/Agenda2013.pdf

Djerf-Pierre, Monika (2007). "The gender of journalism: The structure and logic of the field in the twentieth century". Nordicom review, v. 28, pp. 81-104.

http://www.nordicom.gu.se/sites/default/files/kapitelpdf/248_248_djerf-pierre1.pdf

EFJ (2012). Survey report on women in journalists' unions in Europe. IFJ/EFJ Conference on gender equality in journalists' unions. Confronting the financial crisis, empowering women, Athens.

http://www.ifj.org/fileadmin/images/Gender/Gender documents/IFJEFJ_Survey_Report_on_Women_in_Unions_ in_Europe.pdf

EIGE (2013). Review of the implementation of the Beijing platform for action in the EU member states: Women and 
the media. Advancing gender equality in decision-making in media organisations. Luxembourg: European Institute for Gender Equality. ISBN: 9789292182342

https://doi.org/10.2839/73389

Gallagher, Margaret (1995). An unfinished story: Gender patterns in media employment. Paris: Unesco. ISBN: 923 1032089

Gallagher, Margaret (2001). Gender setting: New agendas for media monitoring and advocacy. New York: Zed Books. ISBN: 9781856498449

Global media monitoring project (2015). Who makes the news? Toronto: WACC.

http://whomakesthenews.org

IWMF (2011). Global report on the status of women in the news media. Washington: International Women's Media Foundation. ISBN: 9780615452708

Rush, Ramona R. (1989). "Communications at the crossroads: The gender gap connection". En: Rush, Ramona R.; Allen, Donna (eds). Communications at the crossroads: The gender gap connection. Norwood, NJ: Ablex, pp. 3-19. ISBN: 9780893914813

Rush, Ramona R.; Buck, Elisabeth; Ogan, Christine (1982). "Nuevas tecnologías: la mujer y la revolución de las comunicaciones". Chasqui, v. 4 (julio-septiembre), pp. 88-97. https://doi.org/10.16921/chasqui.v0i4.1702

Rush, Ramona R.; Oukrop, Carol E.; Ernst, Sandra W. (2004). "Appendix. Original 1972 research report (more than you ever wanted to know) about women and journalism education". En: Ramona R. Rush; Carol E. Oukrop; Pamela J. Creedon (eds.) (2004): Seeking equity for women in journalism and mass communication education: $A 30$ year update: Mahwah, NJ: Lawrence Earlbaum, pp. 415-452. ISBN: 1135624003, 9781135624002

Rush, Ramona R.; Oukrop, Carol E.; Sarikakis, Katharine (2005). "A global hypothesis for women in journalism and mass communications: The ratio of recurrent and reinforced residuum". Gazette, v. 67, n. 3, pp. 239-253. https://doi.org/10.1177/0016549205052226

Soriano, Jaume; Cantón, María-José; Díez, Mercè (2011). "La pseudofeminización de la profesión periodística en España". Zer, v. 10, n. 19, pp. 35-52.

http://www.ehu.eus/zer/hemeroteca/pdfs/zer19-02-soriano.pdf

Van-Zoonen, Liesbet (1998). "One of the girls?: The changing gender of journalism". En: Carter, Cynthia; Branston, Gill; Allan, Stuart (eds.). News, gender and power. London: Routledge, pp. 33-46. ISBN: 9780415170161

Worlds of journalism study (2016). Aggregated data on key variables - Sociodemographic backgrounds: Gender. Munich: Worlds of journalism study.

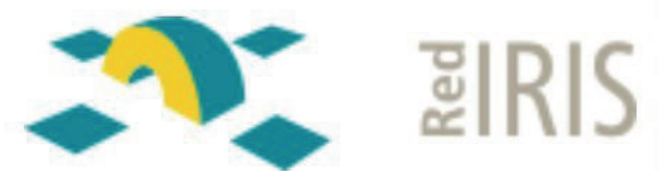

https://www.rediris.es/list/info/iwetel.html

\section{IWETEL}

Foro para profesionales de bibliotecas y documentación

Con unos 6.000 miembros, IweTel es la mayor lista de distribución en castellano para debatir y estar al día sobre temas de biblioteconomía y documentación.

Fue creada en 1993 por Tomàs Baiget, como complemento de Information World en Español (IWE), revista que en 1999 pasó a denominarse El profesional de la información (EPI).

Desde 1998 IweTel está alojada en el servicio de listas de RedIRIS, siendo posible consultar en sus archivos estos 18 años de la historia de la documentación en España:

https://listserv.rediris.es/cgi-bin/wa?AO=IWETEL

La lista cuenta con 4 moderadores que permanentemente filtran los mensajes para evitar spam, mensajes inapropiados, anuncios, mensajes repetidos, etc.:

David Gómez (Observatorio de la Infancia de Andalucía), Isabel Olea (EPI, León),

Nieves González-Fernández-Villavicencio (Universidad Pablo de Olavide, Sevilla), Tomàs Baiget (EPI, Barcelona).

Puedes suscribirte a IweTel en:

https://listserv.rediris.es/cgi-bin/wa?SUBED1=IWETEL\&A=1 